\title{
PENERAPAN ASAS ULTIMUM REMIDIUM DALAM PENEGAKAN HUKUM TINDAK PIDANA UNDANG-UNDANG INFORMASI DAN TRANSAKSI ELEKTRONIK
}

\author{
Hisbul Luthfi Ashsyarofi
}

Fakultas Hukum Universitas Islam Malang

Jalan MT. Haryono No. 193 Malang, 65144, 0341 551932,Fax:0341 552249

Email : hisbulluthfi@unisma.ac.id

\begin{abstract}
The application of criminal law that was originally as an effort / last way (Ultimum Remedium) became the first effort/way (Primum Remedium) especially in applying Law No. 11 of 2008 as amended by Law No. 19 of 2016 on Information and Electronic Transactions (UUITE) In this research using a type of normative legal research using statue approach, conceptual approach, and case approach. This study aims to find out how the application of ultimum remedial principle in the study of criminal law, How to reconstruct the criminal policy of the use of Law No. 11 of 2008 on amendments to Law No. 19 of 2016 on ITE. Surely this requires the existence of over criminalization on the application of criminalization that ensures the existence of disharmony in the application of criminal law, which negates the sense of humanity.
\end{abstract}

Keywords: Ultimum Remidum, Restorative Justice, LAW ITE

\section{ABSTRAK}

Penerapan hukum pidana yang semula sebagai upaya/cara terakhir (Ultimum Remedium) menjadi upaya/cara pertama (Primum Remedium) terutama dalam menerapkan UndangUndang Nomor 11 Tahun 2008 sebagaimana telah diubah atas Undang-undang No 19 Tahun 2016 Tentang Informasi dan Transaksi Elektronik (UUITE) Pada penelitian ini mengunakan jenis jenis penelitian hukum normatif dengan mengunakan Pendekatan Perundang-Undangan (Statue Approach), Pendekatan konseptual (Conseptual Approach), dan pendekatan kasus (Case Approach). Penelitian ini bertujuan untuk mengetahui bagaimanakah penerapan asas ultimum remidium dalam kajian hukum pidana, Bagaimana rekontruksi kebijakan kriminal penggunaan Undang-undang Nomor 11 Tahun 2008 tentang perubahan Atas Undang-Undang Nomor 19 tahun 2016 tentang ITE. Tentunya hal ini menyebapkan adanya over ciminalization pada penerapan pemidanaan yang menyebapkan adanya ketidak harmonisan dalam penerapan hukum pidana, dimana meniadakan rasa kemanusiaan.

Kata Kunci : Ultimum Remidum, Restorative Justice, UU ITE

\section{PENDAHULUAN}

Hukum pidana indonesia mengenal asas Ultimum Remidium yang merupakan salah satu asas yang menyatakan bahwa hukum pidana adalah upaya terakhir dalam hal penegakan hukum setelah norma-norma hukum lainnya tidak bekerja secara efektif. Dengan demikian hukum pidana tidak bisa dibuat sembarangan, sesuai kehendak hati dan diskriminatif, penggunaan hukum pidana harus memperhatikan sikap kehati-hatian serta memikirkan dampak dari penggunaan hukum pidana itu sendiri.

Van Eikama Hommes mengatakan bahwa asas hukum itu tidak boleh dianggap sebagai norma-norma hukum yang konkrit, akan tetapi perlu dipandang sebagai dasar-dasar umum atau petunjuk-petunjuk bagi hukum 
yang berlaku. Pembentukan hukum praktis perlu berorientasi pada asas-asas hukum tersebut. Dengan kata lain asas hukum ialah dasar-dasar atau petunjuk arah dalam pembentukan hukum positif. ${ }^{1}$

Jadi, penerapan asas ultimum remidium merupakan jalan tengah yang menguntungkan bagi semua pihak, baik itu sebagai korban, sebagai pelaku maupun untuk kepentingan masyarakat luas. Namun dalam perkembangannya saat ini, materi muatan yang memuat sanksi pidana yang berkaitan dengan sanksi pidana penjara hampir selalu dimuat dalam setiap undang-undang. Oleh karena itu ada pergeseran politik hukum (Legal Policy) mengenai penerapan hukum pidana yang semula sebagai upaya/cara terakhir (Ultimum Remedium) menjadi upaya/cara pertama (Primum Remedium). ${ }^{2}$ Seharusnya politik hukum (Legal Policy) mengedepankan sanksi pidana yang lain misal denda.

Hukum pidana dapat menjadi premum remidium jika korban sangat besar, tersangka/terdakwa merupakan recidivist, dan kerugian tidak dapat dipulihkan (irreparable). ${ }^{3}$ Misal tindak pidana pengulangan, teorisme, narkoba. Menurut
Sudikno Mertokusumo, ${ }^{4}$ hukum yang berfungsi sebagai perlindungan kepentingan manusia dalam penegakannya harus memperhatikan 3 (tiga) unsur fundamental hukum, antara lain: kepastian hukum (Rechtssicherheit), kemanfaatan (Zweckmassigkeit) dan keadilan (Gerechtigkeit).

Oleh karena itu, dalam menentukan pemberian sanksi pidana dalam suatu undangundang perlu memperhatikan ketiga unsur fundamental hukum tersebut karena pada dasarnya itulah yang menjadi hakikat dari tujuan hukum. Wirjono Prodjodikoro mengatakan bahwa ultimum remedium merupakan norma-norma atau kaidah-kaidah dalam bidang hukum tata negara dan hukum tata usaha negara harus pertama-tama ditanggapi dengan sanksi administrasi, begitu pula norma-norma dalam bidang hukum perdata pertama-tama harus ditanggapi dengan sanksi perdata. Hanya, apabila sanksi administrasi dan sanksi perdata ini belum mencukupi untuk mencapai tujuanmeluruskan neraca kemasyarakatan, maka baru diadakan juga sanksi pidana sebagai pamungkas (terakhir) atau ultimum remedium. ${ }^{5}$

\footnotetext{
1 Notoamidjojo, sebagaimana dikutip oleh Sudikno Mertokusumo, (2006), Mengenal Hukum Suatu Pengantar, Yogyakarta: Liberty. Hlm. 5.

2 Muladi dan Romli Atmasasmita menggunakan istilah primum remedium, (lihat, misalnya, Muladi, (2013), Romli Atmasasmita, (2012))

3 Romli Atmasasmita., (2010), Globalisasi dan Kejahatan Bisnis, Cetakan Ke-1, Jakarta: Kencana Prenada Media Group. Hlm. 192.

4 Op. Cit. Hlm. 128.

5 Wirdjono Prodjodikoro, (2003), Asas-Asas Hukum Pidana di Indonesia, Bandung; Refika Aditama. Hlm. 17.
} 
Undang-Undang Nomor 11 Tahun 2008 sebagaimana telah diubah atas UndangUndang Nomor 19 Tahun 2016 Tentang Informasi dan Transaksi Elektronik (UUITE) telah mengatur larangan perbuatan pendistribusian informasi elektronik dan/atau dokumen elektronik yang mengandung muatan penghinaan dan/atau pencemaran nama baik melalui media sosial sebagai sarana.

Akan tetapi ketentuan yang mengatur tentang hal itu dipandang tidak memberi landasan yang kuat, baik dari aspek yuridis, filosofis, maupun sosiologis, sebab dapat menimbulkan multitafsir, apakah untuk efek pencegahan,atau penghukuman atau tujuan pengekangan kebebasan berpendapat.

Bahkan delik aduan membuat Pasal 27ayat (3) UUITE memiliki keterbatasan dimana dapat mengancam kebebasan berpendapat, membungkam mereka yang vokal seperti aktivisis antikorupsi, jurnalis. Norma penghinaan dan/atau pencemaran nama baik didalam Pasal 27 ayat (3) UU ITE dan didalam KUHPidana adalah sama, bedanya terletak pada mediumnya, pelaku, acaman pidananya, dan unsur di muka umum ${ }^{6}$ Pasal pencemaran nama baik atau delik reputasi dalam Pasal 27 ayat (3) UU ITE cacat bawaan, ketidakjelasan rumusan, dan inkonsitensi hukum pidana. $^{7}$ Selama ancaman pidana maksimal 6 tahun penjara dan/atau denda Rp.1.000.000.000,- (Satu Milyar Rupiah) di dalam Pasal 27 ayat 3 UU ITE tidak direvisi, maka memberatkan mereka yang di anggap melanggar yang di anggap melanggar Pasal ini. Pelaku langsung bisa ditahan selama penyelidikan karena hukumannya di atas 5 tahun penjara. Ukuran kejahatan Pasal 27 ayat (3) UU ITE setara dengan perkara pencurian bahkan bisa melebihi hukuman para koruptor.

Sepanjang tahun 2019 sampai 2020 banyak aktivis ditetapkan tersangka oleh kepolisian karena diduga melanggar UU ITE misal aktivis HAM Dandhy Dwi Laksono berstatus tersangka setelah dikenakan Undang-Undang ITE pasal yang dikenakan adalah pasal ujaran kebencian terhadap individu atau kelompok berdasarkan suku, agama, ras dan antargolongan pasal 28 ayat (2) jo pasal 45 A ayat (2) Undang-undang Nomor 11 Tahun 2008 tentang perubahan atas undang-undang nomor 19 tahun 2016 tentang ITE dan/atau pasal 14 dan pasal 15 undang-undang 1 tahun 1946 tentang hukum pidana, ${ }^{8}$ atau kasus farid gaban pada bulan Mei tahun 2020 yang

6 Edwin Pardede, Eko Soponyono, \& Budhi Wishaksono, (2016), Kebijakan Hukum Pidana Dalam Upaya Penegakan Tindak Pidana Pencemaran Nama Baik Melalui Twitter, Diponegoro Law Journal,Volume.5, Nomor 3. Hlm. 4.

7 Suyanto Didik, (Mei-Juni, 2013), Dampak Undang-Undang Ite Terhadap Perubahan Hukum Dan Sosial Masyarakat, Jurnal Ilmiah Widya, Volume 1, Nomor Hlm. 6.

8 Mohammad Bernie, (1 Oktober 2019), Bagaimana Jurnalis Dandhy Laksono Dikriminalisasi soal Kasus Papua?, Diakses pada tanggal __, Dari Tirto.id: https://tirto.id/bagaimana-jurnalis-dandhy-laksonodikriminalisasi-soal-kasus-papua-ei2p. 
dilaporkan karena cuitannya ditwitter "Rakyat bantu rakyat, penguasa bantu penguasa, gimana nih kang Teten Masduki" Farid Gaban dijerat dengan Pasal 28 ayat (2) UU ITE atau Pasal 207 KUHP/Pasal 14 dan Pasal 15 Undang-Undang 1 tahun 1946 tentang Hukum Pidana. ${ }^{9}$

Dalam penelitian ini menggunakan beberapa teori yang dijadikan pisau analisis teori perlindungan hukum dan teori kebijakan hukum pidana (perlindungan hukum yang diberikan kepada masyarakat yang berada diposisi yang lemah, baik secara ekonomis, maupun lemah dari aspek yuridis dengan menggunakan pendekatan perundanganundangan (Statute Approach) dan pendekatan kasus (Case Approach). Jenis penelitian ini menggunakan metode Yuridis Normatif. Penelitian normatif memeriksa/mempelajari penerapan kaidah-kaidah atau norma-norma dalam hukum positif. ${ }^{10}$

\section{PEMBAHASAN}

Tindak Pidana atau delik berasal dari bahasa Latin delicta atau delictum yang dikenal dengan istilah strafbar feit dan dalam KUHP (Kitab Undang-Undang Hukum Pidana) dengan perbuatan pidana atau peristiwa pidana. Kata Strafbar feit inilah yang melahirkan berbagai istilah yang berbeda-beda dari kalangan ahli hukum sesuai dengan sudut pandang yang berbeda pula. Ada yang menerjemahkan dengan perbuatan pidana, tindak pidana dan sebagainya. Dari pengertian secara etimologi ini menunjukan bahwa tindak pidana adalah perbuatan kriminal, yakni perbuatan yang diancam dengan hukuman. Dalam pengertian ilmu hukum, tindak pidana dikenal dengan istilah crime dan criminal. ${ }^{11}$

Hoefnagels, telah mengingatkan pentingnya mempertimbangkan berbagai faktor untuk melakukan kriminalisasi agar tetap menjaga dalil ultimum remedium dan tidak terjadi over criminalization antara lain. ${ }^{12}$

a. Jangan menggunakan hukum pidana dengan cara emosional;

b. Jangan menggunakan hukum pidana untuk mempidana perbuatan yang tidak jelas korban atau kerugiannya;

c. Jangan menggunakan hukum pidana, apabila kerugian yang ditimbulkan dengan pemidanaan akan lebih besar dari pada kerugian oleh tindak pidana yang akan dirumuskan;

d. Jangan menggunakan hukum pidana apabila tidak didukung oleh masyarakat secara kuat;

9 Adi Briantika, (30 Mei 2020), Kasus Farid Gaban: Pemberangusan Kritik Warga Negara, diakses pada tanggal __ Dari Tirto.id:https://tirto.id/kasus-farid-gaban-pemberangusan-kritik-warga-negara-fDED.

10 Jhonny Ibrahim, (2011), Teori dan Metodologi Penelitian Hukum Normatif, Malang; Bayu Media Publishing, Hlm. 295.

11 Andi Zainal Abidin Farid. (1981), Hukum Pidana 1, Jakarta; Gramedia, Hlm. 132.

12 G.P. Hoefnagels. (1973). "The Other Side of Criminology". Holland: Kluwer Deventer. Hlm. 99, 102-106. 
e. Jangan menggunakan hukum pidana apabila penggunaannya; diperkirakan tidak akan efektif;

f. Hukum pidana dalam hal-hal tertentu harus mempertimbangkan secara khusus skala prioritas kepentingan pengaturan;

g. Hukum pidana sebagai sarana represif harus didayagunakan secara serentak dengan sarana pencegahan.

Berpijak kepada alasan tersebut, bisa diartikan bahwa pemidanaan dimaksudkan sebagai alternatif terakhir penghukuman suatu perbuatan pidana. Dengan kata lain, ultimum remedium itu mensyaratkan terlebih dahulu upaya pemberian sanksi lain (non-penal), berupa ganti rugi, denda, peringatan atau hal lainnya sebelum digunakannya sarana hukum pidana berupa penjara (badan). Oleh karena itu, maka kedepan desain hukum pidana Indonesia harus diarahkan mengikuti sistem pemidanaan modern.

Pemidanaan terhadap pelaku kejahatan tidak dapat dipisahkan dari sistem pemidanaan yang dianut oleh sistem hukum di Indonesia. Bagian penting dalam sistem pemidanaan adalah menetapkan suatu sanksi. Keberadaannya akan memberikan arah dan pertimbangan mengenai apa yang seharusnya dijadikan sanksi dalam suatu tindak pidana untuk menegakkan berlakunya norma. Di sisi lain, pemidanaan itu sendiri merupakan proses paling kompleks dalam sistem peradilan pidana karena melibatkan banyak orang dan institusi yang berbeda. ${ }^{13}$

Penetapan sanksi hukum pidana seharusnya melakukan pendekatan rasional. Bila berdasar pada pendekatan rasional, maka kebijakan penetapan sanksi dalam hukum pidana tidak terlepas dari penetapan tujuan yang ingin dicapai oleh kebijakan kriminal secara keseluruhan, yakni perlindungan masyarakat untuk mencapai kesejahteraan.

\section{Teori Perlindungan Hukum}

Satjipto Rahardjo mengatakan bahwa perlindungan hukum adalah:

"Memberikan pengayoman terhadap hak asasi manusia (HAM) yang dirugikan orang lain dan perlindungan itu diberikan kepada masyarakat agar dapat menikmati semua hak-hak yang diberikan oleh hukum" ${ }^{14}$

Maria Theresia Gerne mengartikan perlindungan hukum adalah :

"Berkaitan dengan tindakan untuk melakukan sesuatu dengan (memberlakukan hukum negara secara eksklusif) dengan tujuan untuk memberikan jaminan kepastian hak-hak seseorang atau kelompok orang". ${ }^{15}$

Secara teoritis bentuk perlindungan hukum dibagi menjadi 2 (dua) bentuk, yaitu:

13 Puteri Hikmawati. (November, 2011). Analisis Terhadap Sanksi Pidana Bagi Pengguna Narkotika, Jurnal, Negara Hukum: Volume 2, Nomor 2. Hlm. 332.

14 Satjipto Rahardjo, (2000), Ilmu Hukum, Bandung: Citra Aditya Bakti. Hlm. 54.

15 Maria Theresia Gerne, (2012), "Perlindungan Hukum terhadpa masyarakat hukum adat dalam pengelolaan cagar alam watu ata Kabupaten Ngad, Provinsi Nusa Tenggara Timur, Disertasi, Malang; Program Doktor Ilmu Hukum Fakultas Universitas Brawijaya. Hlm. 99. 
a. Perlindungan yang bersifat preventif, dan

b. Perlindungan yang bersifat rerperesif.$^{16}$

Perlindungan hukum yang preventif merupakan perlindungan hukum yang sifatnya pencegahan. Perlindungan memberikan kesemptan kepada rakyat untuk mengajukan keberatan, sehingga perlindungan hukum ini bertujuan mencegah terjadinya sengketa dan didasarkan kepada kebebasan bertindak, sedangkan perlindungan hukum represif berfungsi untuk menyelesaikan apabila terjadi sengketa, dibagi ke dalam 2 (dua) badan, yaitu:

a. Pengadilan dalam lingkup peradilan umum, dan

b. Instansi pemerintah yang merupakan lembaga banding administrasi. ${ }^{17}$

Hukum hadir dalam masyarakat adalah untuk mengintegrasikan dan mengkoordinasikan kepentingan-kepentingan yang bisa bertubrukan satu sama lain. Pengkoordinasian kepentingan-kepentingan tersebut dilakukan dengan cara membatasi dan melindungi kepentingan-kepentingan tersebut. ${ }^{18}$ Menurut Paton, suatu kepentingan merupakan sasaran hak, bukan hanya karena ia dilindungi oleh hukum, melainkan juga karena ada pengakuan terhadap itu. Hak tidak hanya mengandung unsur perlindungan dan kepentingan, tapi juga kehendak. ${ }^{19}$

Terkait fungsi hukum untuk memberikan perlindungan, Lili Rasjidi dan B. Arief Sidharta mengatakan bahwa hukum itu ditumbuhkan dan dibutuhkan manusia justru berdasarkan produk penilaian manusia untuk menciptakan kondisi yang melindungi dan memajukan martabat manusia serta untuk memungkinkan manusia menjalani kehidupan yang wajar sesuai dengan martabatnya. ${ }^{20}$

Philipus M. Hadjon berpendapat bahwa "Prinsip perlindungan hukum bagi rakyat terhadap tindakan pemerintah bertumpu dan bersumber dari konsep tentang pengakuan dan perlindungan terhadap hak-hak asasi manusia karena menurut sejarahnya di Barat, lahirnya konsep-konsep tentang pengakuan dan perlindugan terhadap hakhak asasi manusia diarahkan kepada pembatasan-pembatasan dan peletakan kewajiban pada masyarakat dan pemerintah. ${ }^{21}$

Perlindugan hukum juga dapat diartikan sebagai tindakan atau upaya untuk melindungi masyarakat dari perbuatan sewenang-wenang oleh penguasa yang tidak sesuai dengan aturan hukum, untuk mewujudkan ketertiban dan ketentraman sehingga memungkinkan manusia untuk

16 Philipus M. Hadjon, (1987), Perlindungan Hukum Bagi Rakyat Indonesia, Surabaya : PT Bina Ilmu. Hlm 2.

17 Ibid.

$18 \quad$, Op.Cit. Hlm. 53.

Ibid. Hlm. 54.

20 Lili Rasjidi dan B. Arief Sidharta, (1994), Filsafat Hukum Madzab dan Refleksi, Bandung: PT. Remaja Rosda Karya. Hlm. 64.

$21 \ldots$ _Loc.Cit. Hlm. 38. 
menikmati martabatnya sebagai manusia. Dalam Negara kesatuan Republik Indonesia (NKRI), konsep perlindungan hukum yang tidak lepas dari perlindungan hak asasi manusia, merupkan konsep Negara hukum yang merupkan istilah sebagai terjemahan dari dua istilah rechstaat dan rule of law. Sehingga, dalam penjelasan UUD RI 1945 sebelum amandemen "Negara Indonesia berdasar atas hukum, (Rechtsstaat), tidak berdasarkan kekuasaan belaka (Machtsstaat)".

\section{Rekontruksi Kebijakan Kriminal}

Penggunaan Undang-Undang Nomor 11

Tahun 2008 Tentang Perubahan Atas

Undang-Undang Nomor 19 Tahun 2016

Tentang Informasi dan Transaksi

\section{Elektronik}

Pasal 28E ayat (3) UU NRI Tahun 1945 sebenarnya mengacu pada cita-cita hukum, nilai-nilai dan pandangan hidup yang terkandung dalam Pancasila mencerminkan pada kelima sila, yang dalam konteks hak atas kebebasan mengeluarkan pendekatan menekankan pada keseimbangan hak dan kewajiban. Dalam hal ini, bahwa kebijakan kriminal terhadap penghinaan dan/atau pencemaran nama baik melalui media sosial sebagai sarana informasi elektronik tetap berpedoman kepada Pancasila, yaitu sila kedua "Kemanusiaan yang Adil dan
Beradab"22. Rekontruksi bertujuan adanya keseimbangan antara kepentingan negara dan kepentingan masyarakat sehingga UU ITE dikembalikan kepada tujuan pembentukannya.

Dalam UU NRI Tahun 1945 Pasal 28E ayat (3) mengatur tentang hak kebebasan berekpresi dan berpendapat, kebebasan mengeluarkan pendapat mencakup untuk mencari, menerima, dan menyebarkan gagasan serta informasi. Kebebasan ini merupakan suatu hak yang memiliki banyak sisi menunjukkan keluasan dan cakupan hukum hak asasi manusia. Kebebasan pengeluaran pendapat dilindungi dalam bentuk verbal maupun tertulis. ${ }^{23}$ Pemerintah perlu berdialog dengan masyarakat terkait dengan kepentingan negara, sehingga kritik dan saran tidka di anggap pencemaran terhadap pemerintah. Kemerdekaan berpendapat merupakan hal yang penting untuk dipahami apabila negara yang dibentuk bertumpu pada kepentingan rakyat. Pendapat secara umum diartikan sebagai gagasan atau pikiran, dalam kehidupan negara Indonesia, seseorang yang mengemukakan pendapatnya atau mengeluarkan pikirannya dijamin secara konstitusional, sehingga tidak terjadi neootoritarianisme.

Merekontruksi nilai kebijakan kriminal terhadap tindak pidana penghinaan dan/atau

22 Gomgom T.P Siregar, (2020), Suatu Analisis mengenai Tindak Pidana Pencemaran Nama Baik melalui Media Elektronik, Bandung; Refika Aditama. Hlm. 189.

23 Ibid. 
pencemaran nama baik melalui media sosial harus dilakukan dengan merekontruksi rumusan Pasal 45 ayat (3) dan Pasal 45A ayat (2) UU ITE. Pasal 27 Ayat (3) juncto Pasal 45 Ayat (1) UU ITE dinilai oleh para pegiat haka sasi manusia sebagai Pasal karet yang rentan disalah gunakan penguasa.Pasal 27 Ayat (3) juncto Pasal 45 Ayat (1) UU ITE dikatakan sebagai kelanjutan dari Kitab UndangUndang HukumPidana (KUHP) sebab pasal tersebut merujuk pada ketentuan Bab XVI Buku II KUHP tentang penghinaan yang termuat dalam Pasal 310 dan 311 KUHP. Mengenai delik yang termaktub dalam Pasal 27 Ayat (3) dan Pasal 28 Ayat (2) UU ITE, mekanis mekriminalisasi seharusnya diubah karena delik yang dikualifikasikan sejatinya bukan delik biasa. Hal tersebut dikarenakan dalam pasal tersebut hanya mengatur kebijakan kriminal terhadap tindak pidana penghinaan dan/atau pencemaran nama baik yang hanya ditujukan untuk masyarakat melalui media sosial. Oleh karena itu, Pasal 45 ayat (3) dan Pasal 45A ayat (2) UU ITE tersebut harus direkontruksikan kembali dengan Maka seharusnya menurut Satjipto Rahardjo, penyelesaian perkara diluar pengadilan (outofcourtsettlement) bukanlah sesuatu yang aneh, tabu, dan luar biasa bagi mereka yang melihat persoalan tersebut melalui optik sosiologi hukum. Sebab bagi sosiologi hukum,fungsi lebih utama ketimbang sekadar bentuk. ${ }^{24}$ Dengan kata lain, keadilan dan kemanfaatan harus diprioritaskan daripada kepastianhukum

\section{Teori Kebijakan Hukum Pidana}

$$
\text { Istilah "Policy" (inggris) atau "Politiek" }
$$

(Belanda). Bertolak dari kedua istilah tersebut maka "kebijakan hukum pidana" dapat disebut juga dengan "politik hukum pidana". ${ }^{25}$

Definisi kebijakan atau kebijakan kriminal dapat dilihat dalam kebijakan kriminal dan kebijakan hukum. Menurut Prof. Sudarto "Kebijakan Hukum" adalah :

a. Upaya menerapkan aturan yang baik dalam kondisi tertentu

b. Pedoman dari lembaga pemerintah atau lembaga resmi untuk membuat pengaturan yang diinginkan untuk menggambarkan apa yang ada di masyarakat agar terwujud apa yang diinginkan di masyarakat itu. ${ }^{26}$

Menurut Robert R. Mayer dan Enest Greenwood, ini dapat dirumuskan sebagai keputusan yang menggambarkan cara paling tepat dan akurat untuk mencapai tujuan bersama. ${ }^{27}$ David L. Sills menjelaskan bahwa definisi kebijakan adalah rencana atau program yang menjelaskan apa yang harus dilakukan tentang masalah spesifik dan bagaimana melaksanakan atau

24 Satjipto Rahardjo, (__ ), Penegakan Hukum Progresif, _____. Hlm. 3.

25 Barda Nawawi Arief, (2016), Bunga Rampai Kebijakan Hukum Pidana, Jakarta; Prenadmedia Group.Hlm. 26.

26 Sudarto, (1983), Hukum Pidan dan Perkembangan Masyarakat, Bandung; Sinar Baru. Hlm. 20.

27 Sebagaimana dikuti oleh Sultan Zanti Arbi dan Wayan Ardana, (1997), Rancangan Penelitian Kebijakan Sosial, Jakarta; CV Rajawali. Hlm. 63. 
mengimplementasikan rencana atau program yang direncanakan atau diprogram.28

Menerjemahkan "Policy" dengan kebijaksanaan seperti Muhadjir Darwin menterjemahkan "Public Policy Analysis" karya Wiliam N Dun dengan "analisa kebijaksanaan publik"29 Selain itu, Barda Nawawi menyatakan bahwa masalah kebijakan hukum pidana bukan hanya pekerjaan rekayasa hukum yang dapat dilakukan dengan cara hukum yang normatif dan dogmatis secara sistematis. Selain itu, pendekatan hukum faktual juga bisa menjadi pendekatan sosiologis, historis dan kooperatif dan bahkan memerlukan pendekatan komprehensif dari berbagai sistem ilmiah lainnya serta pendekatan integral untuk kebijakan sosial dan pembangunan nasional secara umum. ${ }^{30}$ Barda Nawawi mengatakan bahwa pennggulangan dan pencegahan kejahatan harus holistik dan seimbang atara "Penal" dan "Non Penal" pencegahan dan pendekatan kejahatan dengan sarana "Penal" merupakan "Penal policy" atau "Penal law enforcement policy" yang fungsionalisasi dan atau operasinalisasinya melalui beberapa tahap yaitu :

a. Formulasi (kebijakan legislasi);

b. Aplikasi ( kebijakan implementasi); c. Eksekusi (kebijakan eksekusi).

Menurut Barda Nawawi, upaya dan tindakan yang dapat mengarah pada ketentuan hukum pidana yang baik pada prinsipnya tidak dapat dibedakan dari tujuan pencegahan kejahatan melalui penggunaan hukum pidana. Upaya memerangi kejahatan dengan hukum pidana pada prinsipnya juga merupakan bagian dari langkah-langkah penegakan hukum (terutama dalam penegakan hukum pidana). Oleh karena itu, sering diklaim bahwa hukum pidana adalah bagian dari kebijakan penegakan hukum. ${ }^{31}$

Upaya untuk memerangi kejahatan melalui pembentukan hukum pidana juga merupakan bagian integral dari langkah-langkah perlindungan masyarakat. Jika kebijakan pencegahan kejahatan dan pengendalian kejahatan "kebijakan kriminal" dilakukan dengan sarana "kriminal" (hukum pidana), maka kebijakan kriminal (kebijakan berpikir) harus dipahami terutama dalam fase perumusan undang-undang/kebijakan tugas legislatif (legislasi) harus menghormati tujuan kebijakan sosial dalam bentuk "kesejahteraan sosial" dan "pertahanan sosial" (perlindungan masyarakat) dan mengarah pada pencapaian tujuan-tujuan ini.

28 Barda Nawawi Arif, (1996), Kebijakan legislasi Dalam Penanggulangan Kejahatan dengan Pidana Penjara. Semarang; Universitas Diponegoro. Hlm. 63.

29 Wiliam N Dun, (2000), Analisa Kebijksanaan Publik Penyadur Muhadjir Darwin, Yogyakarta; PT Hadindita Graha Widia. Hlm. 37.

30 Ibid.

31 Barda Nawawi, Op. Cit. Hlm. 29. 
Jimly Asshiddiqie menyatakan, bahwa secara teoritis hukum dianggap relevan, sesuai untuk diadopsi dalam pembaharuan hukumika memenuhi beberapa ukuran relevansi, yaitu relevansi sosiologis, relevansi filosofis, dan relevansi teoritis. ${ }^{32}$ Relevansi yuridis, yaitu jika kaidah hukum tersebut tidak bertentangan dengan kaidah-kaidah konstitusi atau tidak bertentangan dengan norma hukum yang tingkatannya lebih tinggi. Relevansi sosiologis yaitu apabila kaidah hukum itu benar-benar diterima dan diakui oleh warga masyarakat. Relevansi filosofis, yaitu jika kaidah hukum tersebut tidak bertentangan dengan cita-cita hukum suatu masyarakat sebagai nilai positif tertinggi dalam falsafah hidup masyarakat itu.

Dari sudut pendekatan kebijakan, maka pembaharauan hukum pidana pada hakikatnya merupakan bagian dari kebijakan sosial, kebijakan kriminal, dan sebagai bagian dari kebijakan penegakan hukum. jika dilihat dari sudut pendekatan nilai, maka pembaharuan hukum pidana pada hakikatnya merupakan upaya melakukan peninjauan dan penilaian kembali (reorientasi dan re-evaluasi) nilainilai sosio-politik, sosio-filosofis, dan sosiokultural yang melandasi dan memberi isi terhadpa muatan normatif dan subtansi hukum pidana yang dicita-citakan. ${ }^{33}$

\section{Paradigma Hukum Pidana Dari Retributif}

\section{Ke Restoratif Justice}

Andi Hamzah memberikan arti sistem pidana dan pemidanaan sebagai susunan (pidana) dan cara pemidanan. Sedangkan M. Sholehuddin menyatakan, bahwa masalah sanksi merupakan hal yang sentral dalam hukum pidana karena seringkali menggambarkan nilai-nilai sosial budaya suatu bangsa. Artinya pidana maengandung tata nilai (value) dalam suatu masyarakat mengenai apa yang baik dan yang tidak baik, apa yang bermoral dan apa yang amoral serta apa yang diperbolehkan dan apa yang dilarang. ${ }^{34}$

Jika mencermati beberapa kasus hampir semuanya dijerat dengan Undang-undang Nomor 11 Tahun 2008 Tentang Perubahan atas Undang-undang Nomor 19 Tahun 2016 tentang tentang Informasi dan Transaksi Elektronik. Sejak kelahirannya, UU Tentang Informasi dan Transaksi Elektronik telah menuai banyak sekali kontroversi dan kritik. Kritik tersebut khususnya ditujukan terhadap perumusan ketentuan pidana yang terkait dengan larangan penyebaran informasi elektronik yang bermuatan; (i) kesusilaan, (ii)

32 Jilmy Asshiddiqie, (1996), Pembaharuan Hukum Pidana Indonesia, Studi Tentang Bentuk -Bentuk Pidana Dalam Tradisi Hukum Fiqih Dan Relevansi Bagi Usaha Pembaharuan KUHP Nasional, Bandung: Angkasa. Hlm. 12.

33 Barda Nawawi, Op. Cit. Hlm. 26.

34 Ekaputra, Mohammad dan Abul Khair. (2010). Sistem Pidana Di Dalam KUHP Dan Pengaturannya Menurut Konsep KUHP Baru. Medan: USU Press. Hlm. 13. 
penghinaan dan/atau pencemaran nama baik, dan (iii) materi yang mengandung materi SARA, serta tingginya ancaman hukuman terhadap larangan tersebut, baik berupa pidana penjara maupun denda, Ketentuan pidana dalam UU ITE dirumuskan secara sangat longgar, multitafsir dan tidak jelas membuat begitu mudahnya setiap pendapat dan ekspresi dilaporkan ke polisi akibat dianggap menghina, mencemarkan nama baik, menodai agama atau ungkapan SARA lainnya.

Ancaman pidana penjara yang tinggi telah berdampak pada mudahnya penegak hukum untuk melakukan tindakan penahanan, pada kenyataannya seringkali dalam proses penyelidikan dan penyidikan tidak menggunakan pendekatan restoratif justice sesuai dengan SE Nomor 8/ VII/ 2018 tentang Penerapan Keadilan restoratif justice Dalam Penyelesain Perkara Pidana atau Keputusan Direktur Jenderal Badan Peradilan Umum Mahkamah Agung RI Nomor 1691/DJU/SK/PS.00/12/2020 tentang Pemberlakuan Pedoman Penerapan Keadilan Restoratif (restoratif justice)

UU ITE dalam penegakannya, meski mengatur secara khusus hukum acaranya, namun prosedur umumnya masih bersandar pada KUHAP, termasuk dalam prosedur penahanan. Selain itu juga, di dalam pasal 27 ayat (3) UU Undang-undang Nomor 11 Tahun 2008 tentang perubahan atas Undang-undang Nomor 19 Tahun 2016 tentang ITE tidak diperlukan alasan pembenar, inilah yang menjadi akar masalahnya sehingga seakanakan doktrin membela diri dan alasan pembenar tidak ada dalam rumusan Pasal 27 ayat (3) ITE.

Sistem pemidanaan retributif, menurut Kant, adalah bahwa pidana tidak dilaksanakan semata-mata sebagai sarana untuk tujuan perbaikan baik bagi si pelaku itu sendiri maupun bagi masyarakat, tetapi dikenakan hanya karena orang yang bersangkutan telah melakukan suatu kejahatan. ${ }^{35}$ Sedikit berbeda dengan Kant, menurut Hegel, persyaratan dapat dipidananya penjahat berdasarkan keadilan dialektik. Kejahatan dilihat sebagai pengingkaran hukum, oleh karena itu setiap kejahatan harus dipidana namun harus ada keseimbangan antara pidana dan kejahatan yang diperbuat. ${ }^{36}$

\section{Sedangkan Restorative Justice adalah} sebuah konsep pemikiran yang merespon pengembangan sistem peradilan pidana dengan menitikberatkan pada kebutuhan pelibatan masyarakat dan korban. ${ }^{37}$ Pendekatan Restorative Justice tegas Marwan Effendy, mensyaratkan adanya suatu kondisi

35 Sebagaiaman dikutip oleh T.J Gunawan, (2015), Konsep Pemidanaan Berbasis Nilai Kerugian Ekonomi, Yogyakarta; Genta Press. Hlm. 70.

36 Sahetapy, (1982), Suatu Studi Khusus Mengenai Ancaman Pidana Mati Terhadap Pembunuhan Berencana, Jakarta; Rajawali. Hlm. 202.

37 _ Op.Cit. Hlm. 100. 
tertentu yang menempatkan keadilan restoratif sebagai nilai dasar yang dipakai dalam merespon suatu perkara pidana. Dalam hal ini disyaratkan adanya keseimbangan fokus antara kepentingan pelaku dan korban, serta memperhitungkan pula dampak penyelesaian perkara pidana tersebut dalam masyarakat. $^{38}$

Keadilan Restoratif sebagai bagian dari penyelesaiaan perkara pidana haruslah diberikan tempat dalam peraturan perundangan yang juga disertai dengan landasan/teori hukumnya. Restorative justice yang dimaksud adalah dalam konsep hukum pidana, bukan hukum perdata/privat dan juga harus dibedakan dengan mediasi dalam hukum perdata/privat, yang merupakan salah satu jenis Alternative Dispute Resolution (ADR). ${ }^{39}$

Bagir Manan, dalam tulisannya menguraikan tentang substansi "Restorative Justice" yang berisi prinsip-prinsip, antara lain: "Membangun partisipasi bersama antara pelaku, korban, dan kelompok masyarakat menyelesaikan suatu peristiwa atau tindak pidana. Menempatkan pelaku, korban, dan masyarakat sebagai "stakeholders" yang bekerja bersama dan langsung berusaha menemukan penyelesaian yang dipandang adil bagi semua pihak (win-win solutions)".

Terhadap kasus tindak pidana yang di lakukan oleh anak, maka restorative justice system setidak-tidaknya bertujuan untuk memperbaiki/memulihkan (to restore) perbuatan kriminal yang dilakukan anak dengan tindakan yang bermanfaat bagi anak, korban dan lingkungannya yang melibatkan mereka secara langsung (reintegrasi dan rehabilitasi) dalam penyelesaian masalah, dan berbeda dengan cara penanganan orang dewasa. yang kemudian akan bermuara pada tujuan dari pidana itu sendiri. ${ }^{40}$

Menurut Barda Nawawi Arief tujuan pemidanaan bertitik tolak kepada "perlindungan masyarakat" dan “perlindungan/pembinaan individu pelaku tindak. $^{41}$

Ciri-Ciri Peradilan Restoratif menurut Muladi : ${ }^{42}$

1. Kejahatan dirumuskan sebagai pelanggaran seseorang terhadap orang lain dan dipandang sebagai konflik;

2. Fokus perhatian pada pemecahan masalah pertanggungjawaban dan kewajiban untuk masa datang;

3. Sifat normatif dibangun atas dasar dialog dan negosiasi;

38 Ibid. Hlm. 12.

39 Ibid. Hlm. 13.

40 Bagir Manan, (2015), Restorative Justice (Suatu Perkenalan): Refleksi Dinamika Hukum Rangkaian dalam Dekade Terakhir, Jakarta: Perum Percetakan Negara RI. Hlm. 10.

41 Barda Nawawi Arief. (2008). Bunga Rampai Kebijakan Hukum Pidana. Jakarta: PT. Kencana Prenada Media Group. Hlm. 98.

42 Muladi, (2015), Kapita Selekta Sistem Peradilan Pidana, (Semarang: BP Universitas Diponegoro, Hlm. $127-$ 129. 
4. Restitusi sebagai sarana perbaikan para pihak, rekonsiliasi, dan restorasi merupakan tujuan utama;

5. Keadilan dirumuskan sebagai hubungan antar hak, dinilai atas dasar hasil;

6. Fokus perhatian terarah pada perbaikan luka sosial akibat kejahatan;

7. Masyarakat merupakan fasilitator di dalam proses restoratif;

8. Peran korban dan pelaku diakui, baik dalam penentuan masalah maupun penyelesaian hak-hak dan kebutuhan korban pelaku didorong untuk bertanggung jawab;

9. Pertanggungjawaban dirumuskan sebagai dampak pemahaman atas perbuatannya dan diarahkan untuk ikut memutuskan yang terbaik;

10. Tindak pidana dipahami dalam konteks menyeluruh, moral, sosial, dan ekonomi dan

11. Stigma dapat dihapus melalu tindakan restoratif.

Keadilan restoratif adalah konsep pemidanaan, tetapi sebagai konsep pemidanaan tidak hanya terbatas pada ketentuan hukum pidana (formil dan materiil). Keadilan restoratif harus juga diamati dari segi kriminologi dan sistem pemasyarakatan.

Dari kenyataan yang ada, sistem pemidanaan yang berlaku belum sepenuhnya menjamin keadilan terpadu (Integrated Justice), yaitu keadilan bagi pelaku, keadilan bagi korban, dan keadilan bagi masyarakat. Hal inilah yang mendorong ke depan konsep keadilan restoratif. ${ }^{43}$

\section{KESIMPULAN}

Pencantuman sanksi pidana dalam undangundang harus mengacu pada prinsip ultimum remedium, yakni penggunaan sanksi pidana merupakan sarana terakhir dalam mengatasi masalah kejahatan di masyarakat.

Penggunaan pidana harus rasionalitas dan proporsionalitas. Rasionalitas maksudnya yaitu hanya dapat diberikan dengan alasan yang dapat dibenarkan. Sementara itu proporsionalitas yaitu pemberian sanksi pidana perlu diseimbangkan dengan kebutuhan Negara dalam rangka menjaga, melindungi dan mempertahankan ketertiban dan keamanan dalam masyarakat. Pidana hanya dapat dibenarkan apabila ada kebutuhan yang bermanfaat bagi masyarakat dan sebaliknya pidana yang tidak diperlukan, tidak dapat dibenarkan dan berbahaya bagi masyarakat.

Dalam hal tindak pidana UU ITE maka perlu ada solusi atau sanksi lain selain penjara, karena sanksi pidana penjara dapat ditangguhkan dan diganti dengan sanksi lainya layaknya denda. Hal ini sesuai dengan tujuan pemidanaan dimana tidak hanya unsur pembalasan saja yang ditekankan.

\section{DAFTAR PUSTAKA}

\section{Peraturan perundang-undangan}

Undang Undang Dasar Negara Republik Indonesia Tahun 1945

Undang-Undang 1 tahun 1946 tentang Hukum Pidana

43 Mudzakir, (2013), Analisis Restorative Justice: Sejarah, Ruang Lingkup, dan Penerapannya, Jakarta; HIm. 28. 
Undang-Undang Nomor 11 Tahun 2008 Tentang Perubahan atas Undang-undang Nomor 19 Tahun 2016 Tentang ITE

\section{Buku}

Andi Zainal Abidin Farid, (1981), Hukum Pidana 1, Jakarta; Gramedia.

G.P. Hoefnagels, (1973), The Other Side of Criminology, Holland; Kluwer Deventer.

Bagir Manan, (2015), Restorative Justice (Suatu Perkenalan): Refleksi Dinamika Hukum Rangkaian dalam Dekade Terakhir, Jakarta; Perum Percetakan Negara RI.

Barda Nawawi Arief, (2016), Bunga Rampai Kebijakan Hukum Pidana, Jakarta; Prenadmedia Group.

(1996), Kebijakan legislasi Dalam Penanggulangan Kejahatan Dengan Pidana Penjara, Semarang; Universitas Diponegoro,

Ekaputra, Mohammad dan Abul Khair. (2010), Sistem Pidana Di Dalam KUHP Dan Pengaturannya Menurut Konsep KUHP Baru, Medan; USU Press.

Gomgom T.P Siregar, (2020), Suatu Analisis mengenai Tindak Pidana Pencemaran Nama Baik melalui Media Elektronik, Bandung; Refika Aditama.

Jilmy Asshiddiqie, (1996), Pembaharuan Hukum Pidana Indonesia, Studi Tentang Bentuk-Bentuk Pidana Dalam Tradisi Hukum Fiqih Dan Relevansi Bagi Usaha Pembaharuan KUHP Nasional, Bandung; Angkasa.

Jhonny Ibrahim, (2011), Teori dan Metodologi Penelitian Hukum Normatif, Malang; Bayu Media Publishing,

Lili Rasjidi dan B. Arief Sidharta, (1994), Filsafat Hukum Madzab dan Refleksi, Bandung; PT. Remaja Rosda Karya.

Muladi, (2015), Kapita Selekta Sistem Peradilan Pidana, Semarang; BP Universitas Diponegoro.

Notoamidjojo, sebagaimana dikutip oleh Sudikno Mertokusumo, (2006),
Mengenal Hukum Suatu Pengantar, Yogyakarta; Liberty.

Philipus M. Hadjon, (1987), Perlindungan Rakyat Bagi Rakyat di Indonesia (Sebuah Studi tentang PrinsipPrinsipnya, Penanganannya oleh Pengadilan dalam Lingkungan Peradilan Umum dan Pembentukan Peradilan Administrasi Negara), Surabaya; PT. Bina Ilmu.

Romli Atmasasmita, (2010), Globalisasi dan Kejahatan Bisnis, Cetakan Ke-1, Jakarta; Kencana Prenada Media Group.

Sahetapy, (1982), Suatu Studi Khusus Mengenai Ancaman Pidana Mati Terhadap Pembunuhan Berencana, Jakarta; Rajawali.

Satjipto Rahardjo, (2000), Ilmu Hukum, Bandung; Citra Aditya Bakti.

(2010), Penegakan Hukum Progresif Jakarta; PT Kompas Media Nusantara.

Sultan Zanti Arbi dan Wayan Ardana, (__ $)$, Rancangan Penelitian Kebijakan Sosial, Jakarta; CV Rajawali.

Sholehuddin, (2003), Sistem Sanksi Dalam Hukum Pidana: Ide Dasar Double Track System dan Implementasinya, Jakarta; PT. Raja Grafindo Persada.

T.J Gunawan, (2015), Konsep Pemidanaan Berbasis Nilai Kerugian Ekonomi, Yogyakarta; Genta Press.

Wiliam N Dun, (2000), Analisa Kebijksanaan Publik Penyadur Muhadjir Darwin Yogyakarta; PT Hadindita Graha Widia.

Wirdjono Prodjodikoro, (2003), Asas-Asas Hukum Pidana di Indonesia, Bandung; Refika Aditama.

\section{Jurnal}

Edwin Pardede, Eko Soponyono, \& Budhi Wishaksono, (2016), Kebijakan Hukum Pidana Dalam Upaya Penegakan Tindak Pidana Pencemaran Nama Baik Melalui Twitter, Diponegoro Law Journal, Volume 5, Nomor 3. 
Maria Theresia Gerne, (2012), Perlindungan Hukum terhadpa masyarakat hukum adat dalam pengelolaan cagar alam watu ata Kabupaten Ngad, Provinsi Nusa Tenggara Timur, Disertasi, Malang; Program Doktor Ilmu Hukum Fakultas Universitas Brawijaya.

Indriyanto Seno Adji. (2016), Sistem Hukum Pidana \& Keadilan Restoratif, Makalah, Disampaikan Sebagai Pembicara pada Focus Group Discussion (FGD) dengan Tema "Pembangunan Hukum Nasional Yang Mengarah Pada Pendekatan Restorative Justice Dengan Indikator Yang Dapat Terukur Manfaatnya Bagi Masyarakat", Jakarta Timur.

Puteri Hikmawati. (November, 2011), Analisis Terhadap Sanksi Pidana Bagi Pengguna Narkotika, Negara Hukum, Volume 2, Nomor 2,.

Suyanto Didik, (Mei-Juni, 2013), Dampak Undnag-undang ITE Terhadap

Perubahan Hukum Dan Sosial Masyarakat, Jurnal Ilmiah Widya, Volume 1, Nomor

\section{Internet}

Mohammad Bernie, (1 Oktober 2019), Diakses pada tanggal __, Dari Tirto.id; https://tirto.id/bagaimana-jurnalisdandhy-laksono-dikriminalisasi-soalkasus-papua-ei2p.

Adi Briantika, (30 Mei 2020), Diakses pada tanggal _ , Dari Tirto.id: https://tirto.id/kasus-farid-gabanpemberangusan-kritik-warga-negarafDED. 